altered in such a manner that the change in magnetic field due to the electron is opposed in direction to the magnetic field in which it is placed. The orbit thus behaves like a diamagnetic body, and on this fact is based Prof. Langevin's theory of the fact that in weak fields most bodies are diamagnetic. On the other hand, if I understand rightly, according to Prof. Righi the effect of introducing the orbit into the magnetic field is to change the radius, but not the angular velocity, and in such a manner that the change in the field due to the orbit is in the same direction as that of the field in which it is placed. The orbit behaves like a paramagnetic body, and it would seem to follow that all bodies should be paramagnetic. The two views are irreconcilable, and-again unless I have misunderstood Prof. Righi-either he or Prof. Langevin must be wrong. I suggested that if he thinks Prof. Langevin is wrong, he should have explained why he thinks so; or if he thinks his view is not inconsistent with that of Prof. Langevin, he should have told us how he removes the apparent inconsistency.

In self-defence, perhaps I may add that I do not think that a diamagnetic body orientates itself in a uniform field, and that I never suggested in any way that I thought so.

I must refrain (in the same manner as Prof. Righi) from noticing his last paragraph. I cannot imagine why he should read into my words such implications. I meant nothing but that the style of the book was admirable, that it was very refreshing to see a wellproduced book once more, but that, in my opinion, the excellence of the production did not compensate for the absence of an index.

And as for $\mathrm{mv}$ anonymity, I venture to believe that most English physicists would identify me from my initials; at any rate, they would recognise that the writer was not one of the small and distinguished band who could claim scientific precedence of Prof. Righi. But in order that any doubts as to my competence or incompetence may be removed, I beg leave now to sign mvself

Norman R. CAMpbell.

Kettlewell, May rgrg.

\section{The Collection and Presentation of Public Statistics.}

IT is a matter of common knowledge to all who have had occasion to use official statistics, whether published or Departmental, that the national and Imperial equipment for obtaining and publishing statistical data is very imperfect in its scope and inadequate in its machinery.

Further, the efforts made are Departmental, are under no common controlling or directing authority, and suffer very gravely from lack of co-ordination.

There is no need to adduce proofs of these statements, or to enumerate the various efforts, fruitless in the main, which have hitherto been made to remedy these defects.

The council of the Royal Statistical Society has appointed a special committee to deal with the subject in the belief that the time is now ripe for a new movement in the direction of reform, and that the consciousness of the existing defects is present to the minds of his Majesty's Ministers, Members of Parliament, and Civil Servants, as well as to others interested in statistics.

It is proposed to petition his Majesty's Government to set up a Parliamentary Committee to examine the whole question of the collection and presentation of public statistics, and to report on means of improvement. It is believed that this method of procedure is more likely to be effective than the pressing of specific proposals on his Majesty's Ministers.

NO. 2594, VOL. IO3]
The officers of the local government and other public bodies, as well as of scientific societies, are being invited to bring the matter at once before their councils. Moreover, publicists and others who are known to be interested are being approached directly.

We ask the courtesy of your columns to lend support to this movement, and we invite your readers to help with their influence and signatures. The council will be glad if all who are disposed to sign such a petition would communicate with the Secretary, Official Statistics Committee, Royal Statistical Society, 9 Adelphi Terrace, W.C.2. A copy of the petition will then in due course be sent to them for signature. Geoffrey Drage,

Chairman, Official Statistics Committee.

Royal Statistical Society, 9 Adelphi Terrace, Strand, London, W.C.2, July Io.

\section{THE FISHERIES AND SCIENTIFIC RESEARCH.}

THERE has been quite unexpected confusion of counsel with regard to post-war reorganisation of the fishing industry. The collapse of the German submarine campaign about the middle of last year left everyone grateful to the fishermen and wondering what ought to be done for them in the future. That feeling "created an atmosphere," and a number of inquiries began. First of all, the English trawler owners anticipated the end of hostilities, and had a scheme of reconstruction ready by the time the Armistice had been granted. This attracted the attention of Lord Ernle, but did not succeed in impressing the War Cabinet (who had by then "other fish to fry "). The Scottish Steam Drifters' Association was equally ready with its scheme, and about the same time appeared the report of the Haldane Committee on the Machinery of Government, with its proposals for the creation of a State Department of Research, which was to take account of fisheries. Next came an inquiry by a committee of the British Science Guild; and then the deliberations of the National Sea Fisheries Protection Association (which are still going on). The subcommittees of the association began to prepare proposals for scientific research, education, and codification of the law. Following that, the Dievelopment Commissioners appointed a committee to advise them as to the best way in which research could be promoted. As if all this were not enough, the International Research Council has now arranged to meet in Brussels on July 18 , and it is expected that interesting matters with relation to the exploration and fisheries of northern seas will be discussed.

Meanwhile, the conditions are very much what were anticipated in the memorandum presented to Lord Ernle last year. Fish is scarce and dear in the retail shops, and abundant and cheap at the ports of landing, for the means of transport have largely broken down. Exporting has become difficult even with Government guarantees. There is no scientific research yet, and no simplification of the administrative procedure. Nothing has been done for the fishermen, the Admiralty scheme 
of co-partnery in the vessels built as patrols during the war having been opposed by the trawler owners because of its financial unsoundness. The vessels themselves are now offered for public sale. The situation obsesses anyone who has anything to do with it, and has become intolerable-if not farcical.

It is to be hoped that the confusion is only the means towards some satisfactory solution of the difficulties, that the time will come when everybody will be thinking alike-a psychological moment, as the phrase goes-and that then the problem will resolve itself. Anything that is published at the present time is interesting in view of this consummation, and several utterances of late seem to help a little. The report of the Executive Committee of the British Science Guild presented to the general meeting on June in last, Prof. Herdman's report to the Lancashire Fisheries Committee, recently issued, and a lecture by Prof. McIntosh, published in the columns of Nature of July 3 and ro, all have interest in this connection. The guild's report will be received with general approval by men of science, though it may offend the Philistines in Government offices and in the industry. It agrees with the recommendations of the Machinery of Government Committee, regards thought and investigation as desirable preliminaries to action, and urges that the organisation of scientific and industrial research should be the task of a State Department presided over by a Minister. Investigations controlled by administrative officials, the report suggests, are likely to be narrowed in scope and abandoned if they should not prove to be "practical." Probably this is true, but one seems to notice that fishery administration is becoming less important than it was, while scientific and industrial research is much more so, and is attracting a greater share of public attention. Development can be helped very much by investigation, but is only likely to be hampered by restrictions and regulations (which have been the motives of the "administration" of the past). Governmental and other fishery authorities are, therefore, unlikely to neglect scientific and industrial research in the future.

Probably both the administrative people and the researchers will approve of Prof. Herdman's summary of the situation. There are, he says, two categories of fishery research, one having practical administrative, and the other speculative, value. And yet there are not two categories, but only one, for the same mechanism of research can, and does, achieve both kinds of results. Practical results raise questions of strictly scientific interest, while speculative results may at any moment become of practical importance. So also there might be two ways of controlling and organising research, one by a Department of State, which might only think and suggest, and the other by the administrative authorities making the universities their instruments. To deprive the authorities of the privilege of doing research would tend to sterilise their activities, while to create a Government Department quite out of touch with the industry would tend to set up a kind of Olympic pedantry. So these two means of controlling research must also be one. In short, Prof. Herdman adopts the methods of Athanasius; and in seeking to reconcile the intransigents suggests a way out from the confusion.

Lastly, Prof. McIntosh, after a long life spent in marine biological research and a greater experience of fishery investigation than anyone else, seeks to summarise his views as to what has been achieved by the International Council for Fishery Investigations during the last dozen years or so. That research was instigated, on one hand, by the "melancholy anticipations of the pessimists," and, on the other, by the far sounder motive of seeking to discover the reasons for seasonal physical and metabolic changes in the ocean and in its inhabitants. Pessimism as to the future of the fisheries was well expressed by Prof. Garstang in his paper on "The Impoverishment of the Sea," and a vigorous optimism was proclaimed by the doyen of marine biologists in his book "The Resources of thế Sea." There were thus two opposed theses, one that the exploitation of the fishing-grounds was exceeding their recuperative power, and the other that fishing operations were carried on on too small a scale to make any appreciable difference. Now nobody is quite sure which thesis is proved, and anybody who is asked to give an opinion will certainly be inclined to hedge.

This back-number controversy, of which Profs. McIntosh and Garstang were the protagonists, has not so much interest for us just now. Some time must elapse before fishery operations will attain, much less surpass, their pre-war intensity; it will be a long time before the transport systems of Europe will be able to take fish everywhere that it is required, and so long as the prices of inferior categories of fish remain high not so much complaint of impoverishment of the superior categories will be heard from the entrepreneurs. But it is certain again to arise, and as we ought to possess the means of closuring it we cannot afford to scrap the mechanism of international investigation or kill the germ of international regulation. Even if it should be proved that the cherished fear of progressive impoverishment is a real one, that would be a result of exceedingly practical importance, 'for we might then be enabled to scrap the machinery of regulations, restrictions, prohibitions, and policing, all of which is expensive to maintain, and intolerable if it is unnecessary. But even then there would arise questions as to means of rendering this superabundance of food available on a greater scale by developing methods of preservation and utilisation in ways not yet attempted. And since man does not live by food alone, an international organisation will have much to do in the promotion of purely oceanographical discovery, which may be regarded as quite properly a part of the activities of civilised communities.

J. J.

NO. 2594, VOL. IO3] 